\title{
DOES FINTECH MATTER FOR INDONESIA'S ECONOMIC GROWTH?
}

\author{
Seema Wati Narayan \\ School of Economics, Finance and Marketing, RMIT University, Melbourne, Australia \\ Email: seema.narayan@rmit.edu.au
}

\begin{abstract}
This paper investigates the role of financial technology (FinTech) in propelling economic growth in Indonesia from 1998 to 2018. The FinTech industry employs a technology-based business model to provide financial services, including lending, payment, investment, and financing services. The study is motivated by endogenous growth theory, which seeks to explain technology as the most important driver of economic growth. The study finds that FinTech startups are positively correlated with Indonesia's economic growth. FinTech firms in their first year are found to be disruptive, but they fail to have serious consequences on Indonesia's economic growth; however, they seem to significantly encourage economic growth in their second year. These findings are derived after accounting for other important growth determinants, namely, capital per labor, foreign direct investment (FDI), stock market development, and trade openness.
\end{abstract}

Keywords: Economic growth; FinTech; Indonesia.

JEL Classification: O47.

Article history:

Received : August 15, 2019

Revised : November 10, 2019

Accepted : : December 15, 2019

Available online : December 19, 2019

https://doi.org/10.21098/bemp.v22i4.1237 


\title{
I. INTRODUCTION
}

The FinTech sector uses technology available to anyone with Internet access to provide financial services at a marginal cost that is below that of traditional operators. The FinTech industry offers new business models for traditional financial activities, such as lending and borrowing funds and the investment and trading of stocks, digital coins, and other commodities. This transformative approach to providing financial services is flexible enough to be adopted by underbanked or new markets. Developing nations, including the least developed ones, are adopting FinTech services more rapidly than developed nations are (Arner et al., 2015). Consistent with economic theory, both elements of FinTech, namely, technology and financial services, provide impetus for economic growth.

Figure 1.

\section{FinTech Start-ups Established (FINTECH_EST) and Cumulative (FINTECH_CUM) Each Year Over the Period 1998-2017}

\begin{abstract}
This figure depicts the growth of the FinTech sector in Indonesia over the period 1998-2017. FINTECH_EST is the number of new established FinTech firms and FINTECH_CUM is the cumulative number of FinTech firms each year. Adopted from Narayan and Sahminan (2018).
\end{abstract}

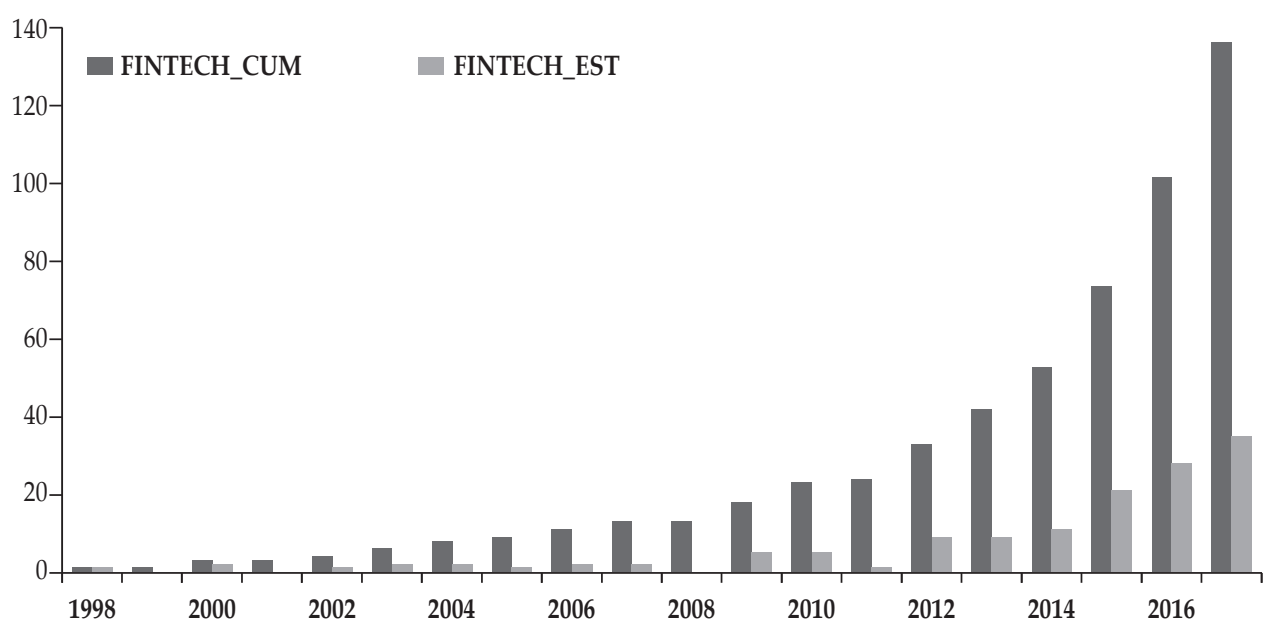

This paper examines the relation between FinTech and economic growth in the context of Indonesia over the period 1998-2017. In Indonesia, small-scale engagements of FinTech startups with the public have been observed since 1998, and only since 2010 has the industry begun to rapidly grow (Figure 1). In Indonesia, FinTech services are still highly concentrated in the major cities and are not capturing the market without access to traditional financial services (Iman, 2018). This is not surprising, since the emergence of FinTech in Indonesia took place against the backdrop of the development of information communication technology, including mobile phones and the Internet (Iman, 2018). World Bank reports that the number of mobile cellular subscriptions in 2017 was close to 450 million, compared to 93 million 10 years before (Figure 2). ${ }^{1}$ Further, in 2013,

World Bank online data was accessed from: https://data.worldbank.org/ 
there were 7.8 secure Internet servers per million people, which rose sharply to 1,824 by 2017 (Figure 3).

Figure 2.

Mobile Cellular Subscription: Indonesia (1997-2017)

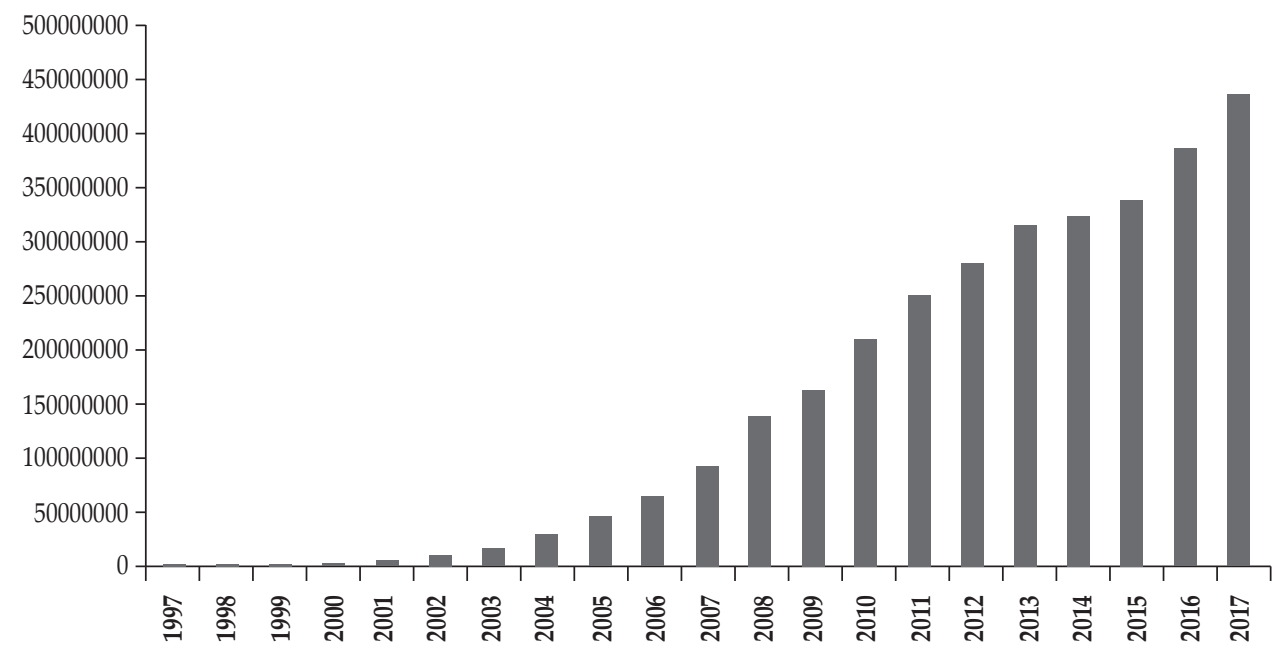

Source : World Bank online Data

Figure 3.

Secure Internet Servers (per 1 million people): 2013:2017

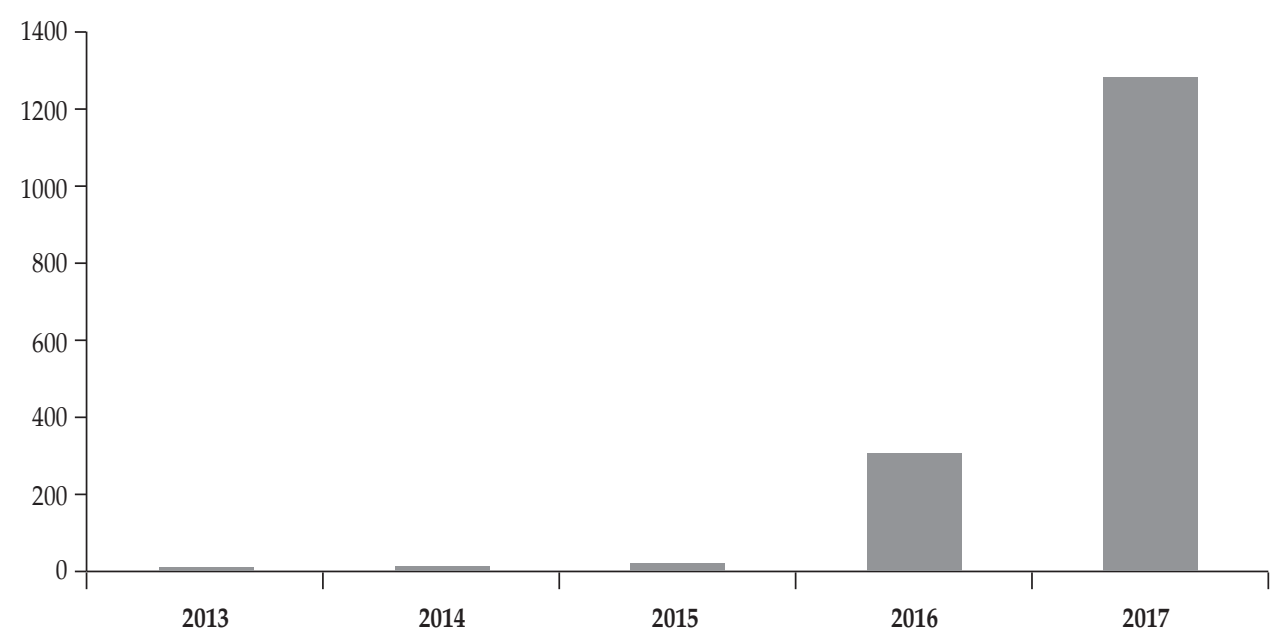

Source : World Bank online data

As in other developing nations, the FinTech sector in Indonesia shows strong growth potential. Euromonitor data indicate that, of 170 million Indonesians who owned mobile phones from 2017, about 130 million used them to access the 
Internet (Iman, 2018). However, 80 million Indonesians have no access to banking and financial services (Iman, 2018). While other studies have examined the FinTech industry, only a few have investigated its economic and financial implications, and there are no studies on the impact of FinTech on economic growth. Several authors show that, as a new and innovative business, FinTech is disrupting the financial services industry (Li et al., 2017; Zalan and Toufaily, 2017). Narayan and Sahminan (2018) present empirical evidence that, in Indonesia, FinTech has the capacity to reduce inflation and strengthen the rupiah against the US dollar. Li et al. (2017) find that the effect of FinTech is positive on bank returns, implying complementarity between traditional banks and FinTech.

This study is the first to investigate the economic implications of FinTech in Indonesia. It employs a dynamic economic growth regression model to examine the relation between FinTech startups and economic growth in Indonesia. The results show that FinTech startups can be disruptive in the first year of their inception, but do not have significant implications for Indonesia's economic growth, as measured by output per labor. However, significant positive economic implications materialize in the second year of FinTech startups. The results take into account other key economic growth factors, namely, trade openness, foreign direct investment (FDI), and stock market development.

The remainder of the paper is organized as follows. The next section develops testable hypothesis. Section III develops the empirical model. Section IV describes the data set for the empirical analyses while Section V presents the empirical analyses. Finally, Section VI provides concluding remarks.

\section{HYPOTHESIS}

To examine the impact of FinTech on economic growth, this paper considers two important characteristics of FinTech: (1) its technology component and (2) its role in providing financial services. No single theory, but, rather, many explain these two important features.

\section{A. FinTech's Technology Side}

The idea that technology is the impetus for economic growth has been intensely studied in the last 73 years, since Solow's (1956) seminal contribution. Solow's growth model shows that, although capital and labor are important production inputs, they fail to explain most of the changes in the output growth rate. The unexplained part of the Solow model is referred to as the state of technology, or the Solow residual factor. Many studies have attempted to explain this technology factor. From this literature, we have come to understand technology as affecting economic growth through a few key channels. Two of these are (1) positive technological spillovers, triggered by investment in new technology, mainly reflected in research and development expenditure (Romer, 1990; Grossman and Helpman, 1991a; Riveria-Batiz and Romer, 1991; Jones, 1995), and (2) technology transfer through economic integration, creating positive externalities and affecting economic growth, such as technology transfers through trade (Grossman and Helpman, 1991b) and technology transfers through FDI or multinational enterprises 
(Riveria-Batiz and Romer, 1991; Baldwin et al. 2005; Ramondo and RodriguezClare, 2010). This literature generally views technology as being positively related to economic growth.

In the banking literature, technology is seen as the solution to reducing the information asymmetry that exists between agents (e.g., borrowers and lenders) in the provision of financial services (Jaffee and Russell, 1976; Stiglitz and Weiss, 1981). In particular, FinTech, through its use of machine learning, is seen as significantly reducing such information asymmetry (Jagtiani and Lemieux, 2018). Machine learning algorithms allow for the quick and easy assessment of borrowers' credit scores, using big data from social media and other sources (Li et al., 2017). Some FinTech firms use blockchain to track investment and financing opportunities and store information, allowing peers to track each other and providing an element of trust (Cai, 2018). This also means that, unlike traditional banks, FinTech lenders do not bear any risk (The Economist, 2015; Li et al., 2017).

These transformative features are making lending and financing more accessible and flexible. The reduction of lending and financing barriers should encourage economic activity in terms of easy access to funds and new investment products, such as digital coins. The new technology employed by the FinTech industry is encouraging financial development. Economic theory has contemplated the role of financial development on economic growth. The endogenous growth theory posits that the effect of financial development on economic growth depends on the risks brought about by the new opportunities (Devereux and Smith, 1994; Obstfeld, 1994).

\section{B. FinTech as a Financial Service Provider}

FinTech, as a new and innovative business, is also seen by many as disrupting the financial services industry (Bower and Christensen, 1995; Christensen et al., 2015; Zalan and Toufaily, 2017; Christensen et al., 2018). According to Christensen et al. (2015), disruption due to an innovation such as FinTech occurs when a new entrant with fewer resources successfully challenges established incumbents. Disrupters have a business model that differs from that of the incumbents', as with FinTech, and provide services that are more affordable, faster, more flexible, and less complex (Christensen et al., 2015). Christensen et al. (2015) theorize that disruptors start by targeting low-end (less sophisticated customers) or new markets and, as the disruptive technologies improve and gain traction, absorb mainstream (highly sophisticated) customers. Hence, equipped with the advantages of efficiency and low cost, disruptors have the capacity to displace incumbents.

Empirical studies suggest that FinTech startups are already reaching mainstream customers (Iman, 2018; Jagtiani and Lemieux, 2018) and affecting some segments of traditional sectors (Zalan and Toufaily, 2017). Zalan and Toufaily (2017) conducted a survey capturing different stakeholders from the financial ecosystem of the Middle East, North Africa, Afghanistan, and Pakistan, beginning in mid-2016. They find that some segments of the banking sector, but not all, are being affected by FinTech. The survey respondents noted that retail banking products, such as consumer payment solutions, customer credit, and 
simple savings products, were the most likely to be disrupted by FinTech, and corporate and private banking structures the least.

Jagtiani and Lemieux (2018), focusing on online lending in the United States, examine Lending Club and Y-14M data reported by US banks with assets over $\$ 50$ billion. The authors find FinTech penetration in highly concentrated markets and areas with few bank branches per capita, as well as in areas where the local economy is not performing well. In the case of Indonesia, Iman (2018) argues that FinTech services are concentrated in major cities and do not capture the market without access to traditional financial services.

Li et al. (2017) have a different perspective on disruption. They describe disruption caused by FinTech in terms of substitution and complementary effects: substitution effects arise from the FinTech sector's low cost and efficiency compared to incumbent banks, which leads to a fall in the value of banks. The complementary effects of FinTech, on the other hand, are likely to arise in situations in which traditional banks work in partnership with the FinTech sector, outsourcing services, venture capital funding, or acquisition, which leads to increase the Banks' value. Li et al. investigate these two effects of the FinTech sector on the returns of 47 US banks from 2010 to 2016 and measure the value of FinTech using FinTech funding. The authors find that FinTech has positive effects on bank returns, implying its complementarity with traditional banks. Li et al. explain that, if there are substitution effects, they are currently much smaller than the complementary effects. Nonetheless, the authors note that the FinTech industry is still relatively small compared to the large US retail banking industry.

Motivated by FinTech's promise of low-cost business solutions in the provision of financial services, Narayan and Sahminan (2018) investigate the impact of FinTech on Indonesia's inflation rate and the exchange rate between the Indonesian rupiah and the US dollar from 1998 to 2017. The authors employ data on the number of FinTech firms and find that FinTech in Indonesia has been able to reduce inflation and strengthen the rupiah against the US dollar. Their study finds that FinTech's impact on inflation is instantaneous, whereas its effect on the exchange rate is delayed. Narayan and Sahminan (2018) provide empirical evidence that the cost of business is indeed reduced through the usage of FinTech.

Our testable hypothesis is therefore as follows: FinTech startups encourage economic growth.

\section{EMPIRICAL MODEL}

To explain the link between FinTech startups and economic activity in Indonesia, we use the endogenous growth model that transpires from the Solow growth model, where economic growth is dependent on capital $(K)$, Labor $(L)$ and a scalar factor, , which is the state of technology:

$$
Y_{t}=A_{t} f\left(K_{t}, L_{t}\right)
$$

In Solow's (1956) model, innovation, knowledge, or technology is the residual factor derived from Equation (1). This residual technology is found to be an important determinant of growth, more so than capital investment or an increase 
in the number of workers (Solow, 1957; Marshall, 1987). Hence, many studies have attempted to test and explain this factor endogenously. ${ }^{2}$ The endogenous growth models endogenize the technology factor. The endogenous model we use takes the following general form:

$$
\frac{Y_{t}}{L_{t}}=f\left(\frac{K_{t}}{L_{t}}, A_{t}\right)
$$

where output and capital appear as a ratio of labor force and are referred to, respectively, as the output per worker, $\frac{Y_{t}}{L_{t}}$, and capital per worker, $\frac{K_{t}}{L_{t}}$. Consistent with the discussion in Section II, we consider FinTech as part of the technology factor, $A_{t}$. The growth model (in logarithmic form, $L$ ) with the effects of FinTech, FinTech, takes the following form:

$$
L\left(\frac{Y_{t}}{L_{t}}\right)=\alpha_{1}+\beta_{1} L\left(\frac{K_{t}}{L_{t}}\right)+B_{2} L F I N T E C H_{t}+B_{3} L Z_{t}+\varepsilon_{1 t}
$$

where, $\alpha_{n^{\prime}} \beta_{n^{\prime}}$ and $\varepsilon_{t^{\prime}}$ with $n=1,2$, are the intercept, coefficients, and error term, respectively; economic activity is measured as the change in the output per worker $\left(\frac{Y_{t}}{L_{t}}\right)$, and capital is represented as the ratio of the labor force $\left(\frac{K_{t}}{L_{t}}\right)$ or capital per worker; and $Z_{t}$ includes other sources of technology, such as trade openness $(O P E N)$, FDI (FDI) as a percentage of the gross domestic product (GDP), and stock market capitalization as a percentage of the GDP, which is a common measure of financial development (FDEV). Our inclusion of the $Z_{t}$ factors as determinants of economic growth acknowledges the literature on endogenous economic growth theory established by studies including Romer (1990) and Grossman and Helpman (1991b) that shows the importance of technology transfer, trade, human capital, ${ }^{3}$ and financial liberalization to domestic economic growth.

2 Few authors note the relevance of the endogenous growth model or the importance of technology for Indonesia. Juhro et al. (2020) test various endogenous growth models for Indonesia within the long and short run. Other authors, such as Rachman et al. (2015) and Rath and Hermawan (2019), examine the role of other forms of technology, namely, information and communication technologies, on economic growth in Indonesia.

3 Health (Qureshi and Mohyuddin, 2006) and education (Lucas, 1988) are considered vital elements for increasing human capital, which is seen as an important determinant of economic development. Data from the World Bank on the Human Capital Index (HCI) or related variables are insufficient for Indonesia. Following Feenstra et al. (2015), we extracted HCI data from the Penn World Tables, but they proved to be an $I(2)$ variable over the period 1998-2017. Since we only covered $I(1)$ variables in the models, we avoided using this human capital data. Instead, we used World Bank data on health and education, namely, government expenditures on health as a percentage of the GDP, life expectancy at birth, the share of the labor force with an advanced education (percentage of the total working age population with an advanced education), and the share of the labor force with a basic education (percentage of the total working age population with a basic education). In the modeling scheme employed in this paper (see Section V), none were found to be significant determinants of economic activity. In the models with these health- and education-related variables, the key results relating to FinTech, noted in Section V, remain intact. The data on health and education factors are available on request. 
Although it is common practice to include trade openness as one of the key determinants of economic growth (following Grossman and Helpman, 1991b), Ramondo and Rodriguez-Clare (2010) examine the channels through which openness affects growth. The authors build an endogenous growth model by considering three channels: trade, multinational enterprises and the direct diffusion of ideas. The study finds that the gains from the diffusion of ideas are large compared to the gains from trade and multinational enterprises. The study also finds several developing countries that are significantly poorer than they should be, given their size and exposure to trade and multinational enterprises, and this is due to the lack of direct adoption of foreign ideas. All in all, Ramondo and Rodriguez-Clare find that the diffusion of ideas is quantitatively more important than trade and multinational enterprises in accounting for gains from openness.

As noted above, FDI is an important channel of economic integration and is traditionally associated with the transfer of knowledge, technology, and management practices and systems from the home countries of multinational enterprises to their host countries (Doytch and Narayan, 2016). Baldwin et al. (2005) develop an endogenous growth model where multinational enterprises and/or FDI plays a direct role in determining growth, by increasing the extent of global technological transfer/spillover in the innovation sector. Using industrylevel data from seven Organization for Economic Co-operation and Development nations, the authors find evidence of only technology transfer, not knowledge transfer. The study finds that the transfer of new or superior technologies through FDI and export channels can increase economic growth. Significant literature shows a positive link between FDI and economic growth for developing nations (Lai et al., 2006; Sun, 2010, 2011; Lui and Agbola, 2014). Bende-Nabende and Ford (1998) show a positive influence of FDI but a negative influence of openness for Taiwan from 1959 to 1995 . The authors explain that the unexpected negative effect of openness on economic growth is related to effects of the oil crises during the sample period. Febiyansah (2017) shows the positive effects of inward FDI on economic activity in Indonesia in the long run, from 2000 to 2012.

Financial markets have the ability to affect growth, both directly and indirectly. These markets are sources of the funds necessary for acquiring new assets (or capital) required for growth. Further, a direct increase in wealth due to increased financial market activities can lead to a multiplier effect that sees an increase in activities across the economy. Endogenous growth models, on the other hand, argue that financial liberalization/development facilitates risk sharing, which should enhance production specialization and capital allocation, but the implications on economic growth can be negative or positive (Devereux and Smith, 1994; Obstfeld, 1994). In examining six major emerging East Asian countries from 1990 to 2002, Gamra (2009) shows that full liberalization of the financial sector is associated with reduced growth outcomes, whereas partial liberalization is associated with positive growth outcomes. Naceur et al. (2008) find that, for 11 Middle East and North American countries, while stock market liberalization had no effect on economic and investment growth, stock market development led to negative effects in the short run and positive effects in the long run. The authors argue that the preconditions for the positive impact of stock market development include a more developed stock market prior to liberalization, less government intervention, and limited trade liberalization. 
Using panel data, Compton and Giedeman (2011) show that the positive effect of banking development diminishes as institutions (the rule of law, corruption levels, and bureaucratic quality) become more developed. However, they find that stock market development and institutional development show no such effect. Their study suggests that, although banking development is dependent on institutions, stock market development is not. On the other hand, using the case of sub-Saharan African countries, Ahmed (2013) brings to light the destabilizing role of financial liberalization in intensifying the risk of financial fragility and contributing to domestic capital flight. Yanping, et al. (2016) find that, in the case of Western China, financial development is more important than human capital in promoting GDP growth. Hsueh, Hu, and Tu (2013) examine the case of financial development and economic growth for 10 Asian countries. They find that only some Asian countries, including Indonesia, show a positive and significant relation between the two variables, flowing from financial development (private and domestic credit, monetary aggregates, and bank variables) to economic growth.

\section{DATA}

The study employs annual data series from 1998 to 2017, with the start year marking the beginning of FinTech startups in Indonesia. Table 1 presents the data set. The data on FinTech startups established each year are adopted from Narayan and Sahminan (2018), and the other economic/financial data series on Indonesia are extracted from the World Bank database. ${ }^{4}$

Table 1.

Data Set

This table clarifies the definition and source of the data used in the paper for empirical analysis.

\begin{tabular}{lll}
\hline $\begin{array}{l}\text { Variables } \\
\text { Used }\end{array}$ & \multicolumn{1}{c}{ Indicator Name } & \multicolumn{1}{c}{ Indicator Code } \\
\hline Exch & $\begin{array}{l}\text { Official exchange rate (LCU per US\$, period } \\
\text { average) } \\
\text { Foreign direct investment, net inflows (\% of GDP) } \\
\text { FDI }\end{array}$ & BX.KLT.DINV.WD.GD.ZS \\
FDEV & $\begin{array}{l}\text { Market capitalization of listed domestic companies } \\
(\% \text { of GDP) }\end{array}$ & CM.MKT.LCAP.GD.ZS \\
FINTECH & FINTECH_CUM & Narayan and Sahminan (2018) \\
$Y$ & GDP (constant LCU) & NY.GDP.MKTP.KN \\
Health & Life expectancy at birth, total (years) & SP.DYN.LE00.IN \\
K & Gross capital formation & NE.GDI.TOTL.ZS \\
Lab & Labor force, total & SL.TLF.TOTL.IN \\
Open & Trade (\% of GDP) & NE.TRD.GNFS.ZS \\
\hline
\end{tabular}

4 The capital stock data for Indonesia, consistent with the data of Feenstra et al. (2015), were extracted from the Penn World Tables. When we examine the unit root property of the data as a ratio of the labor force $(k)$, we find this variable is $I(2)$ from 1998 to 2017. On the other hand, capital proxied using the World Bank's gross capital formation data provides an $I(1)$ variable for capital per labor hour. Since the inclusion of $I(1)$ variables in the model is theoretically meaningful, we use only the gross capital formation data in this paper. 
A preliminary analysis of the data is presented in Table 2. Panel A reports descriptive statistics. We find that, from 1998 to 2017, the real GDP or output per labor was approximately US\$6,155, and investment on capital per worker was around US\$1,380. In cumulative terms, the number of FinTech startups averaged 29.

Table 2.

Data Description and Preliminary Analysis: Economic Growth and FinTech

This table presents the common statistics, and other preliminary analysis for the variables examined. In Panel A, Ly, Lk, and LFINTECH_CUM are output per worker, capital per worker, and FINTECH_CUM in logarithmic form. In Panel B, D indicates that the variables are in first difference form.

\begin{tabular}{|c|c|c|c|c|c|c|}
\hline & $y$ & $k$ & FINTECH & FDI & FDEV & OPEN \\
\hline Variables & $\begin{array}{l}\text { GDP (US\$, } \\
2010 \text { constant)/ } \\
\text { Labour force }\end{array}$ & $\begin{array}{c}\text { Gross } \\
\text { Capital } \\
\text { formation } \\
\text { (US\$)/ } \\
\text { Labour force }\end{array}$ & $\begin{array}{l}\text { No. of } \\
\text { established } \\
\text { firms }\end{array}$ & $\begin{array}{l}\% \text { of } \\
\text { GDP }\end{array}$ & $\begin{array}{l}\text { MKT } \\
\text { CAP } \\
\text { (\% of } \\
\text { GDP) }\end{array}$ & $\begin{array}{l}\text { Trade } \\
(\% \text { of } \\
\text { GDP) }\end{array}$ \\
\hline Mean & 6154.843 & 1379.714 & 28.9 & 1.049 & 34.109 & 55.727 \\
\hline Median & 5894.703 & 990.72 & 13 & 1.603 & 38.096 & 54.829 \\
\hline Maximum & 8465.851 & 2672.781 & 137 & 2.916 & 51.278 & 96.186 \\
\hline Minimum & 4443.36 & 278.705 & 1 & -2.757 & 13.465 & 37.421 \\
\hline Std. Dev. & 1271.395 & 944.975 & 36.787 & 1.602 & 13.255 & 13.038 \\
\hline $\mathrm{CV}$ & 0.207 & 0.685 & 1.273 & 1.527 & 0.389 & 0.234 \\
\hline \multicolumn{7}{|c|}{ Panel A: Unit Root Test } \\
\hline & $L R y$ & $L k$ & $\begin{array}{l}\text { LFINTECH } \\
\text { CUM }\end{array}$ & FDI & $F D E V$ & OPEN \\
\hline \multirow[t]{2}{*}{ Levels } & 0.728 & -0.303 & 2.189 & -1.806 & -2.668 & -0.716 \\
\hline & 0.990 & 0.908 & 0.997 & 0.367 & 0.097 & 0.818 \\
\hline \multirow[t]{2}{*}{ First difference } & -14.069 & -8.927 & -6.474 & -4.517 & -5.909 & -5.297 \\
\hline & 0.000 & 0.000 & 0.000 & 0.002 & 0.000 & 0.001 \\
\hline \multicolumn{7}{|c|}{ Panel B: Unconditional Correlations } \\
\hline & $D L y$ & $D L k$ & DLFINTECH & DFDI & DFDEV & DOPEN \\
\hline \multicolumn{7}{|l|}{ DLy } \\
\hline \multirow[t]{2}{*}{ DLk } & 0.031 & 1 & & & & \\
\hline & 0.900 & & & & & \\
\hline \multirow[t]{2}{*}{ DLFINTECH } & 0.180 & 0.047 & 1 & & & \\
\hline & 0.461 & 0.849 & & & & \\
\hline \multirow[t]{2}{*}{ DFDI } & 0.315 & -0.050 & -0.330 & 1 & & \\
\hline & 0.189 & 0.839 & 0.167 & & & \\
\hline \multirow[t]{2}{*}{ DFDEV } & -0.450 & 0.026 & -0.352 & -0.031 & 1 & \\
\hline & 0.053 & 0.917 & 0.140 & 0.900 & & \\
\hline \multirow[t]{2}{*}{ DOPEN } & 0.670 & -0.044 & 0.302 & 0.343 & -0.616 & 1 \\
\hline & 0.002 & 0.858 & 0.210 & 0.151 & 0.005 & \\
\hline
\end{tabular}

From 1998 to 2017, FDI averaged 1\% of Indonesia's GDP, while financial development depicted through stock market capitalization was 34\% of Indonesia's GDP. Trade openness, measured as exports plus imports as a percentage of the GDP, averaged $56 \%$. Of all the variables, FDI is the most volatile, followed by the FinTech variable. The evolution of the data from 1998 to 2017 is presented in Figure 4. 
Figure 4 .

\section{Variables Employed}

This figure captures all the variables in raw form. $y$ is real GDP as a ratio of labour; $k$ is capital per labour; FinTech is cumulative number of established firms; FDI is as a percentage of GDP; FDEV is stock market capitalization; OPEN is trade as a percentage of GDP.
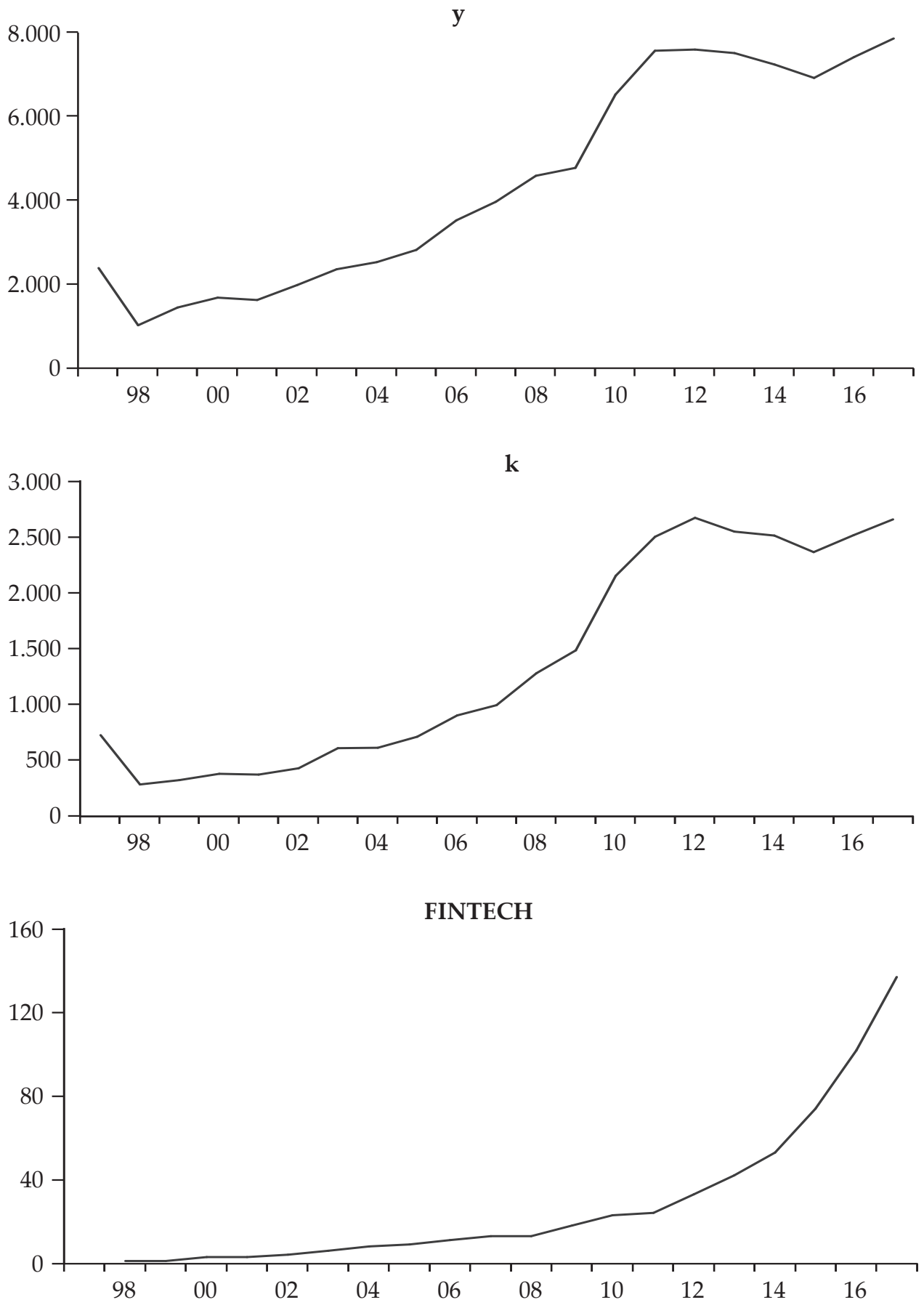
Figure 4 .

Variables Employed (Continued)

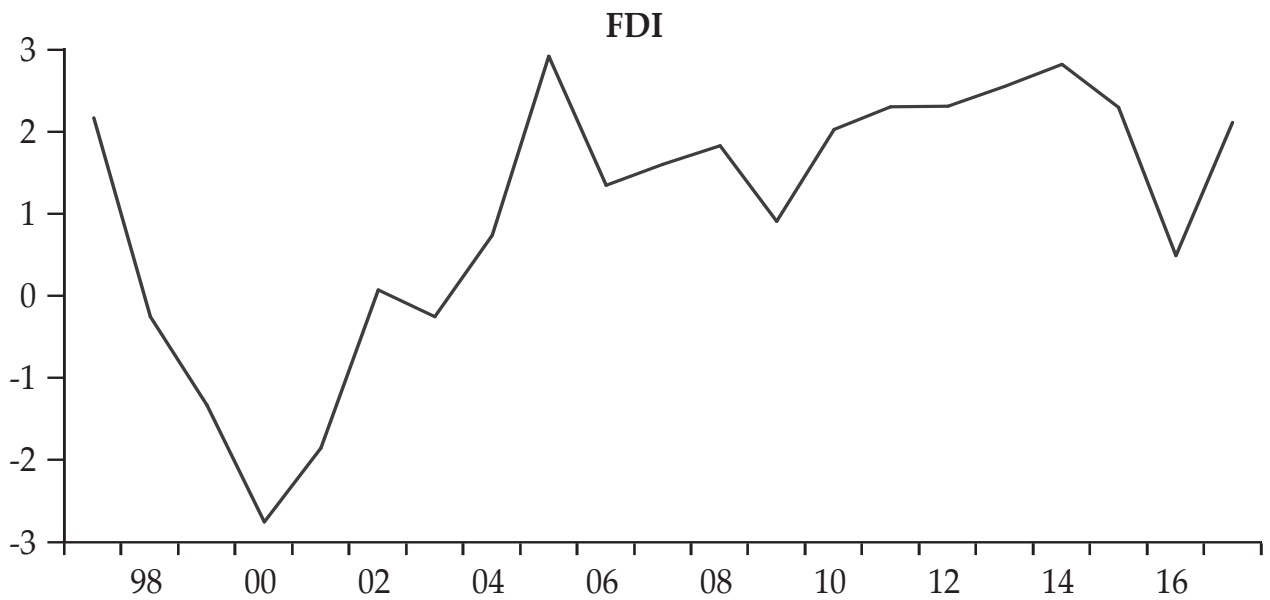

Fdev
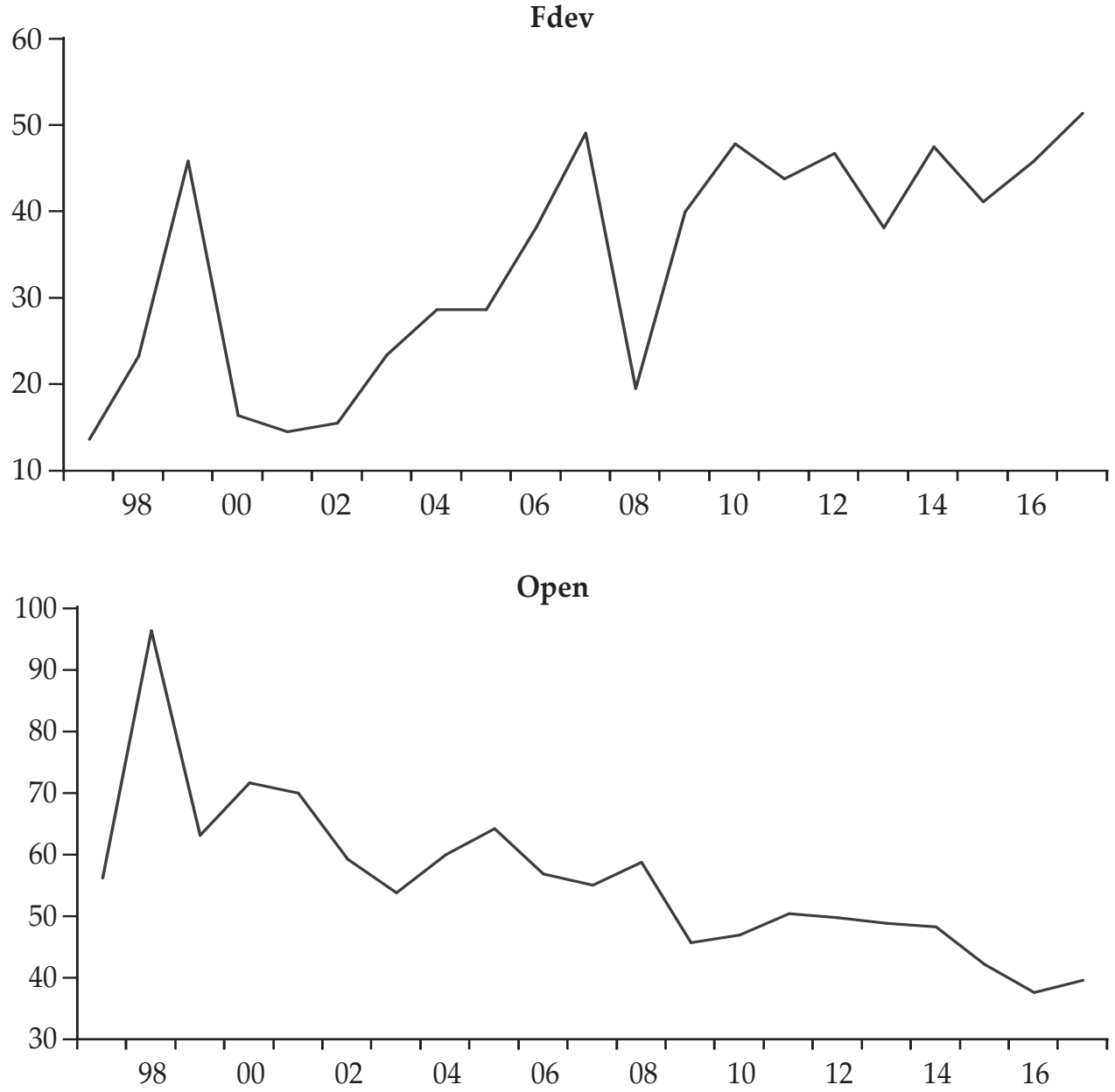
The time series properties of the variables are examined using the standard augmented Dickey-Fuller (ADF) test. This test uses the logarithmic form of the real GDP and capital per worker and FinTech, with the rest expressed as a percentage of the GDP. The results presented in Table 2, panel 2 show that all the variables are $I(1)$. In other words, the variables are stationary in their first-difference form. All the variables in the regression analysis (as depicted in Equation (4)) appear in stationary form.

The literature, beginning with Perron (1989), argues that a structural break(s) in the intercept and/or trend, if unaccounted for in the test, leads to results that are biased toward non-stationarity, or a unit root. The dependent variable, namely, the logarithm of the output per worker, is re-examined using the Perron's (1989) modified ADF test, which allows for one structural break in the intercept to confirm its time series properties, as well as to check for the presence of one structural break. The test was conducted with an intercept only. The lag selection is dependent on the Schwarz information criterion, and the break selection is based on minimizing the Dickey-Fuller statistic. The results indicate a level break in 2004, with the dependent variable only becoming stationary in its first difference form. ${ }^{5}$ It should be noted that, when the Perron (1989) test is specified with an intercept, and trend, and a level break, we find that the output per worker (in logarithmic form) is stationary in its level form (or is $I(0)$ ), with a structural break in 2006. This study uses the first difference of the dependent variable because it depicts the growth in the output per worker. Hence, in the regression analysis, we only use the output per worker in its first-differenced form.

The pairwise unconditional correlations between the variables are either insignificant or below 50\%, which means that multicollinearity is not an issue for the regression analysis (Table 2, Panel3). Looking at the correlations of the variables with the output per worker, we note a strong positive and significant correlation between output and investment per worker, consistent with theory. However, we do not observe any significant correlation between the output per worker and the financial variables, trade openness, or FinTech yet. In the next section, we use more sophisticated growth models to explore the dynamic relations in a multivariate setting (see Equation (4)).

\section{EMPIRICAL ANALYSIS}

This section discusses the findings related to the economic growth model depicted in Equation (4). The focus is indeed on the effects of FinTech on economic growth and how this new sector is impacting Indonesia's economy.

5 The structural break in 2004 was included in the regression analysis (Model (2)). The structural break proved to be insignificant in Model (2) and did not affect the key findings of the paper. 


\section{A. Econometric Models}

To allow for a dynamic relation between economic growth and FinTech, our main econometric model takes the following form: ${ }^{6}$

$$
\begin{aligned}
& D L y_{t}=\alpha_{1}+\beta_{1} \sum_{p=1}^{2} D L y_{t}+\beta_{2} \sum_{p=0}^{2} D L k_{t}+\beta_{3} \sum_{p=0}^{2} \text { DLFINTECH }_{t}+\beta_{4} \sum_{p=0}^{2} Z_{t}+ \\
& B_{5} L y_{t-1}+\varepsilon_{1 t}
\end{aligned}
$$

All the variables are as in Equation (3) and expressed in logarithmic form $(L)$. From here on, $y_{t}$ and $k_{t}$ are the output per worker $\left(\frac{Y_{t}}{L_{t}}\right)$ and the ratio of capital to the labor force $\left(\frac{K_{t}}{L_{t}}\right)$, respectively. To avoid the spurious regression problem, all the variables in Equation (4) appear in their stationary form. Hence, consistent with the unit root test, all the variables, except the lag of the dependent variable, appear in the model in the first difference form (D). A lag structure with a lag of up to two is applied. We address for any endogeneity using the one-period lag of the output per labor, $y_{t-1}$.

We estimated two versions of Equation (4), which we refer to as Models (1) and (2). Model (1) covers the standard growth model with only capital per worker, while Model (2) extends the standard growth model with FinTech and other determinants of economic growth, such as trade openness, FDI, and the financial development variable. The models' selection criteria and diagnostics are reported in Table 3. A total of six and 32 models were evaluated to find the best fit Models (1) and (2), respectively. The standard growth model has a insignificant F-statistic, which suggests that Model (1) is not sufficient for modeling economic growth in Indonesia. Model (2), on the other hand, is found to be appropriate. The diagnostic tests on the residuals of the models suggest that all the models follow a normal distribution, serial correlation is rejected for both models, and neither of the models suffers from Breusch-Pagan-Godfrey heteroskedastic error terms (Table 3).

The estimated coefficients $(\beta)$ and the probabilities that $\beta=0$ for the two models are presented in Table 4. Of key interest is the response of output growth to FinTech startups. We find that FinTech startups had a negative (positive) effect on output in the first (second) year of being established. This means that FinTech firms were disruptive in the first year of establishment, as discussed by Christensen et al. (2015). ${ }^{7}$ Consistent with Li et al. (2017), our results indicates that the substitution effects of FinTech dominate the complementary effects. However, the resulting negative effects of FinTech on economic growth are nonsignificant. In the second year of establishment, FinTech startups had a positive effect on the economic growth of Indonesia, which implies that the increase in the number of established firms increased economic growth in the second year over the period from 1998 to 2017. According to Li et al. (2017), this means that, in the second year

${ }_{6}$ Several versions of the economic growth model were used, with different combinations of growth factors, as expressed in this model, as well as with other variables, as specified in footnotes 2 and 3. In most cases, we found results similar to those of Model (4). The variables were not modeled together in a single equation because of the small sample size.

7 For the full discussion, see Section II. 
of newly established FinTech startups, the complementary effects relating to these firms were significantly greater than the substitution effects, helping the sector contribute to the growth of the Indonesian economy.

Table 3.

Model Selection and Diagnostic Tests

Models correspond to those used in Table 3. Model 1 covers the standard growth model which consider capital per labour $(k)$. Model (2) considers FinTech and other variables, namely trade openness (DOPEN), FDI (DFDI), the financial development variable (DFDEV). Model (3) covers all variables in Model (2) plus the structural break in real output per worker (LRY) which takes the value of 1 in 2004, and zero, otherwise (SB_2004). The best model was selected using the Akaike information criteria (AIC).

\begin{tabular}{|c|c|c|c|c|}
\hline \multirow{2}{*}{ Description } & \multicolumn{2}{|c|}{ (1) } & \multicolumn{2}{|c|}{ (2) } \\
\hline & Stat. & Prob. & Stat. & Prob. \\
\hline Model F-statistic & 1.117 & 0.402 & 3.700 & 0.048 \\
\hline Jarque-Bera & 2.374 & 0.305 & 0.952 & 0.621 \\
\hline \multicolumn{5}{|c|}{ Breusch-Godfrey Serial Correlation LM Test } \\
\hline F-statistic & 0.026 & 0.974 & 0.551 & 0.608 \\
\hline \multicolumn{5}{|c|}{ Heteroskedasticity Test: Breusch-Pagan-Godfrey } \\
\hline F-statistic & 0.542 & 0.741 & 0.493 & 0.850 \\
\hline Number of models evaluated & \multicolumn{2}{|c|}{6} & \multicolumn{2}{|c|}{32} \\
\hline Sample (adjusted) & \multicolumn{2}{|c|}{20002017} & \multicolumn{2}{|c|}{20002017} \\
\hline Included observations & \multicolumn{2}{|c|}{18} & \multicolumn{2}{|c|}{18} \\
\hline Maximum dependent lags & \multicolumn{2}{|c|}{1} & \multicolumn{2}{|c|}{1} \\
\hline
\end{tabular}

Table 4.

Economic Growth Model with FinTech

Models correspond to those used in Table 3. Model 1 covers the standard growth model which considers capital per labour $(k)$. Model (2) considers FinTech and other variables, namely trade openness (DOPEN), FDI (DFDI), the financial development variable (DFDEV). Finally, ${ }^{* * *}$, ,*** denote the level of significance at $10 \%, 5 \%$, and $1 \%$, respectively.

\begin{tabular}{lcccc}
\hline \multirow{2}{*}{ Variables } & \multicolumn{3}{c}{ (1) } & \multicolumn{2}{c}{ (2) } \\
\cline { 2 - 5 } & Coef. & Prob. & Coef. & Prob. \\
\hline DLy(-1) & -0.111 & 0.297 & $-0.911^{* * *}$ & 0.003 \\
DLk & 0.007 & 0.577 & -0.014 & 0.471 \\
DLk(-1) & -0.041 & 0.134 & -0.021 & 0.159 \\
DLk(-2) & 0.014 & 0.118 & & \\
DOPEN & & & 0.000 & 0.917 \\
DFDI & & & $0.004^{*}$ & 0.097 \\
DFDI(-1) & & & $0.014^{* *}$ & 0.000 \\
DFDEV & & & $0.001^{*}$ & 0.096 \\
DLFINTECH & & & -0.002 & 0.863 \\
DLFINTECH(-1) & & & $0.027^{* *}$ & 0.026 \\
Ly(-1) & -0.013 & 0.343 & $0.031^{*}$ & 0.056 \\
C & 0.266 & 0.266 & $-0.482^{*}$ & 0.087 \\
Adjusted R-squared & 0.033 & & 0.614 & \\
\hline
\end{tabular}




\section{B. Impact of Other Factors on Economic Growth}

We find the following results for the other factors of economic growth. Capital per worker $(K)$ is found to have an insignificant effect on output growth. This result is apparent in both Models (1) and (2). All the other factors, except trade openness, are found to be highly relevant in the determination of economic growth in Indonesia. These results are not unheard of in the literature, and we briefly discuss the results.

Trade openness and FDI are regarded as important drivers of economic growth. Trade contributed around 55\% of Indonesia's GDP, on average, over the period from 1998 to 2017. In comparison, FDI contributed only 1\% to Indonesia's GDP over the same period. ${ }^{8}$ However, our findings suggests that FDI has a positive and significant effect, more so in the second year of a FinTech startup than in the first year, while the effect of trade openness on economic growth is positive but nonsignificant.

Explanations of the potency, or lack thereof, of these variables have been given by, for example, Grossman and Helpman (1991b), who explore trade as a driver of economic growth, and Ramondo and Rodriguez-Clare (2010), who examine openness in terms of trade, FDI, and the diffusion of ideas and their impact on economic growth. Similarly, Riveria-Batiz and Romer (1991), Baldwin et al. (2005), and Ramondo and Rodriguez-Clare, (2010) have studied the role of technology transfer through FDI and multinational enterprises. Grossman and Helpman (1991b) suggest that trade can influence economic growth through positive externalities from technology transfer. In the same way, studies such as that of Riveria-Batiz and Romer (1991) discuss technology spillover from FDI. More importantly, Ramondo and Rodriguez-Clare (2010) conclude that the direct adoption of foreign ideas, and not the extent of the exposure to trade, makes trade an effective engine of growth.

Few studies have explained the current state of technology transfer in Indonesia, and these all conclude that the technology transfer channels are operating at suboptimal levels. Thalib's (2017) normative legal research finds that, while the Indonesian government imposed performance requirements in the regulation of foreign investment for a faster technology transfer effect, the surrounding legislation is weak and not enforced. Soekarno, et al. (2009) describe the technology transfer challenges in Indonesia, specifically those relating to Indonesia's turbine maintenance and overhaul industry. The authors argue that the key challenges to technology transfer are the factory workers' lack of basic skills, a lack of supporting industries, the workforce's low level of English proficiency, and the low credibility of the government entities that oversee the industry in Indonesia.

This study reveals a positive linkage between stock market development and economic growth. More specifically, our study shows that an increase in stock market capitalization has encouraged economic growth in Indonesia, and vice versa. Economic theory notes that the growth of stock markets can have both a

8 Further, Lindblad (2015) notes that, although the FDI climate in Indonesia has been less restrictive since 1994 and has witnessed an increase in the flow of FDI, the Asian financial crisis (1997-1998) eroded investor confidence: "it was several years into the 21st century before any appreciable recovery of incoming FDI took place" (p. 233). Despite weakness in the inflow of FDI in the early part of our sample, our results indicate the effectiveness of FDI in influencing growth (see Figure 4). 
positive and a negative influence on economic activity (Devereux and Smith, 1994; Obstfeld, 1994). For Indonesia, it seems that, over the study period, the positive effects on growth are able to compensate for the negative effects in the short run.

\section{CONCLUSION}

This paper develops a framework for analyzing the economic impact of FinTech. Our findings imply that the FinTech sector, although still small relative to the traditional financial services sector, is making an impact on the Indonesian economy. Our findings from 1998 to 2017 suggest that, when new FinTech firms are established, their disruption can cause discomfort for the economy, as documented in the literature. Although first-year FinTech firms fail to have any serious economic consequences in Indonesia, in the second year, their impact on economic growth is significant and positive. Indonesia's experience shows that FinTech has a delayed positive effect and that some degree of disruption is to be expected as new firms become established.

The delayed but positive effects of FinTech highlight, to some extent, the complementarity between traditional financial services providers and FinTech startups. Indonesia shows evidence of banks working with FinTech, mostly by providing venture capital. In several other countries, incumbents are acquiring FinTech startups, which can assist in reducing the disruptive nature of the new technology. Our study also highlights the significant impact on economic growth that FinTech is making, alongside traditional growth factors, such as trade, FDI, and financial markets. Given the economic significance of the FinTech sector, it is important that the central bank and the government in Indonesia be supportive, as well as innovative and vigilant, in their dealings with this emerging industry.

Finally, this study is based on a short sample period and is therefore limited in terms of the dynamics and growth factors captured in the single-equation model. The availability of panel data and more time series data should allow future studies to verify the current study's findings. In this regard, the findings of this paper are preliminary and should be used to further the work in this field. Further, although the present study applies data on the cumulative number of FinTech startups, future studies may also consider data that capture the value of these firms. The influence of different segments of FinTech on economic growth would also be of interest.

\section{REFERENCES}

Ahmed, A. D. (2013). Effects of Financial Liberalization on Financial Market Development and Economic Performance of the SSA Region: An Empirical Assessment. Economic Modelling, 261-273.

Arner, D. W., Barberis, J., Buckley, R. P. (2015). The Evolution of FinTech: A New Post-Crisis Paradigm. University of Hong Kong Faculty of Law Research Paper No 2015/047. https://hub.hku.hk/bitstream/10722/221450/1/Content.pdf

Baldwin, R., Braconier, H., Forslid, R. (2005). Multinationals, Endogenous Growth, and Technological Spillovers: Theory and Evidence, Review of International Economics, 13, 945-963. 
Bende-Nabende, A., and Ford, J. L. (1998). FDI, Policy Adjustment and Endogenous Growth: Multiplier Effects from a Small Dynamic Model for Taiwan, 19591995, World Development, 26, 1315-1330.

Bower, J. L. and Christensen, C. M. (1995). Disruptive Technologies: Catching the Wave, Harvard Business Review, 73, 43-53.

Cai, C. W. (2018). Disruption of Financial Intermediation by FinTech: A Review on Crowdfunding and Blockchain, Accounting and Finance, 58, 965-992.

Christensen, C. M., McDonald, R., Altman, E. J., and Palmer, J. E., (2018). Disruptive Innovation: An Intellectual History and Directions for Future Research, Journal of Management Studies, 55(7), 1043-1078.

Christensen, C. M., Raynor, M. E., McDonald, R. (2015). What is Disruptive Innovation? Harvard Business Review, December. https://hbr.org/2015/12/whatis-disruptive-innovation

Chu, A. C., Cozzi, G., Furukawa, Y., and Liao, C-H. (2017). Inflation and Economic Growth In Schumpeterian Model with Endogenous Entry of Heterogenous Firms. European Economic Review, 98, 392-409.

Compton, R. A., Giedeman, D. C. (2011). Panel Evidence on Finance, Institutions and Economic Growth. Applied Economics, 43, 3523-3547.

Devereux, M. B., and Smith, G. W. (1994). International Risk sharing and Economic Growth. International Economic Review, 35, 535-550.

Doytch, N., and Narayan, S. (2016). Does FDI Influence Renewable Energy Consumption? An Analysis of Sectoral FDI Impact on Renewable and Nonrenewable Industrial Energy Consumption. Energy Economics, 54, 291-301.

Febiyansah, P. T. (2017). Indonesia's FDI-Exports-GDP Growth nexus: Trade or investment - driven? Bulletin of Monetary Economics and Banking (Buletin Ekonomi Moneter dan Perbankan), 19, 470-487.

Feenstra, R. C., Inklaar, R., and Timmer, M. P. (2015). The Next Generation of the Penn World Table. American Economic Review, 105, 3150-3182.

Gamra, S. B., (2009). Does Financial Liberalization Matter for Emerging East Asian Economic Growth? Some New Evidence. International Review of Economics and Financial Studies, 18, 392-403.

Grossman, G, M., and Helpman, E., (1991a). Innovation and Growth in the Global Economy. Cambridge, Mass.: MIT Press, 1991.

Grossman, G. M., and Helpman, E., (1991b). Trade, Knowledge Spillovers and Growth. European Economic Review, 35, 517-526.

Hsueh, S-J., Hu, Y-H., and Tu, C-H. (2013). Economic Growth and Financial Development in Asian Countries: A Bootstrap Panel Granger Causality Analysis. Economic Modelling, 32, 294-301.

Iman, N., (2018). Assessing the Dynamics of FinTech in Indonesia. Investment Management and Financial Innovations, 15, 293-303.

Jaffee, D. M., and Russell, T., (1976). Imperfect Information, Uncertainty and Credit Rationing. Quarterly Journal of Economics, 90, 651-666.

Jagtiani, J., and Lemieux, C., (2018). Do FinTech Lenders Penetrate Areas That Are Underserved By Traditional Banks? Journal of Economics and Business, 100, 4354.

Jones, C. I., (1995). R\&D Based Models of Economic Growth, Journal of Political Economy, 103(4), 795-784. 
Juhro, S. M., Narayan, P. K., Iyke, B. N., and Trisnanto, B. (2020). Is There a Role for Islamic Finance and R\&D in Endogenous Growth Models in the Case of Indonesia? Working Paper (Under revision).

Marshall, E., (1987). Nobel Prize for theory of Economic Growth, Science (New York, N.Y.), 238(4828), 754-5.

Mishkin, F., (1992). Is the Fisher Effect for Real? A Re-examination of The Relationship between Inflation and Interest Rates. Journal of Monetary Economics, 30, 195-215.

Li, Y., Spigt, R., and Swinkels, L., (2017). The Impact of FinTech Start-Ups on Incumbent Retail Banks' Share Prices, Financial Innovation, 26, 1-16.

Lai, M. Y.,Peng, S. J. and Bao, Q. (2006). Technology Spillovers, Absorptive Capacity and Economic Growth. China Economic Review, 17, 300-20.

Lindblad, T. J. (2015). Foreign Direct Investment in Indonesia: Fifty Years Of Discourse. Bulletin of Indonesian Economic Studies, 51, 217-237

Lucas, E. R. (1988). On the Mechanics of Economic Development. Journal of Monetary Economics, 22, 3-42.

Lui, W. S., and Agbola, F. W., (2014). Regional Analysis of the Impact of Inward Foreign Direct Investment on Economic Growth in the Chinese Electronic Industry. Applied Economics, 46, 2576-2592.

Naceur, S. B., Ghazouani, S., and Omran, M., (2008). Does Stock Market Liberalization Spur Financial and Economic Development in The MENA Region? Journal of Comparative Economics, 36, 673-693.

Narayan, S., Sahminan, S., (2018). Has FinTech Influenced Indonesia's Exchange Rate and Inflation? Bulletin of Monetary Economics and Banking (Buletin Ekonomi Moneter dan Perbankan), 21, 303-322.

Obstfeld, M., (1994). Risk-taking, Global Diversification and Growth. The American Economic Review 84, 1310-1329.

Perron, P., (1989). The Great Crash, The Oil Price Shock, and The Unit Root Hypothesis. Econometrica, 57, 1361-1401

Qureshi, H. A., and Mohyuddin, H. A. (2006). Health Status, Disease, and Economic Development: A Cross Country Analysis. The Journal of Developing Areas, 39, 121-128.

Rachman, S., Gregory, M., Narayan, S., (2015). The Role of ICT Services on Indonesian SME Productivity, 2015 International Telecommunication Networks and Applications Conference (ITNAC), accessed from: https:// ieeexplore.ieee.org/document/7366807.

Ramondo, N., and Rodriguez-Clare, A., (2010). Growth, Size and Openness: A Quantitative Approach. The American Economic Review, 100, 62-67.

Rath, B. N., \& Hermawan, D. (2019). Do Information and Communication Technologies Foster Economic Growth in Indonesia? Buletin Ekonomi Moneter dan Perbankan, 22, 103-122

Riveria-Batiz, L. A. and Romer, P. M. (1991). Economic Integration and Endogenous Growth. Quarterly Journal of Economics, 106, 531-555.

Romer, P. M., (1990). Endogenous Technological Change, Journal of Political Economy, 89, S71-S102. 
Soekarno, S., Damayanti, S. M., and Wibowo, P. M. S. (2009). Technology Transfer Challenges in Indonesia: An Experience from Industry Turbine Overhaul. The Asian Journal of Technology Management, 2, 28-32.

Solow, R. M., (1956). A Contribution to the Theory of Economic Growth. The Quarterly Journal of Economics, 70, 65-94.

Solow, R. M.., (1957). Technical Change and the Aggregate Production Function. The Review of Economics and Statistics, 39, 312-320.

Stiglitz, J. E., and Weiss, A., (1981). Credit Rationing in Markets with Imperfect Information. American Economic Review, 71, 393-410.

Sun, S. (2010). Heterogeneity of FDI Export Spillovers and Its Policy Implications: The Experience of China, Asian Economic Journal, 24, 289-303.

Sun, S. H. (2011). Foreign Direct Investment and Technology Spillovers in China's Manufacturing Sector, The FDI and Economic Growth in Chinese Electronic Industry. Chinese Economy, 44, $25-42$.

Thalib, A. (2017). Technology Transfer in Indonesia and China: A Comparative Study, Jurnal Hukum Ius Quia Iustum. 23(2), 251-270. https://journal.uii.ac.id/ IUSTUM/article/view/6582

The Economist. (2015). The FinTech Revolution, The Economist, May 9.

Yanping Huang, Yu Liu \& Huakun Wu (2016). The Finance-Growth Nexus and Poverty Reduction in Western China. Emerging Markets Finance and Trade, 52, 513-521

Zalan, T., Toufaily E., (2017). The Promise of FinTech in Emerging Markets: Not as Disruptive. Contemporary Economics, 11, 415-430.

World Bank, (2019). Online Data. https://data.worldbank.org/ 